\title{
Vertiginous Syndrome Associated with Incorrect Anesthesia Technique to Block the Maxillary Nerve via the Greater Palatine Canal: Case Report and Anatomic Correlation with Cadaveric Parts
}

\author{
Síndrome Vertiginoso Asociado a Técnica Anestésica Incorrecta para Bloquear el Nervio Maxilar \\ vía Canal Palatino Mayor: Reporte de Caso y Correlación Anatómica en Piezas Cadavéricas
}

\author{
Reinaldo Soto $^{*, * *}$; Felipe Cáceres ${ }^{* * *}$ \& Jorge Lankin ${ }^{* * * *}$
}

SOTO, R.; CÁCERES, F. \& LANKIN, J. Vertiginous syndrome associated with incorrect anesthesia technique to block the maxillary nerve via the greater palatine canal: Case report and anatomic correlation with cadaveric parts. Int. J. Morphol., 32(3):786-788, 2014.

SUMMARY: The anesthetic technique through the greater palatine canal seeks to block the maxillary nerve in the pterygopalatine fossa and anesthetize a large area, including the pulp and periodontium of the arch in question. After applying this technique in a patient, it failed to obtain the expected result. The patient began to experience dizziness, nausea, vomiting and the sensation of fluid in the ear. She was evaluated in both the emergency room of the Hospital Parroquial de San Bernardo and at a private clinic without accurate diagnosis. Only symptomatic treatment was provided. The next day she was discharged with reduced symptoms, which disappeared completely during the day. We propose the hypothesis of a diffusion of the anesthetic solution into the middle and inner ear through the auditory tube. This diffusion would explain the vestibular symptoms and the absence of anesthesia in the expected areas. We carried out an anatomic correlation in cadavers, following the path of a needle from the palatal mucosa to the pharyngeal opening of auditory tube. We conclude that the vertiginous syndrome could be due to an incorrect application of the technique, with the needle entering the auditory tube and spreading the anesthetic solution into the middle ear.

KEY WORDS: Vertigo; Dental anesthesia; Auditory tube; Maxillary nerve.

\section{INTRODUCTION}

The anesthetic technique through the greater palatine canal seeks to anesthetize the maxillary nerve at the pterygopalatine fossa. This requires the needle be inserted $2 \mathrm{~mm}$ anterior to the projection of the greater palatine foramen on the palatal mucosa. This opening is usually located between first and second upper molar, approximately $1 \mathrm{~cm}$ medially from the alveolar ridge. The needle must be inserted in a lateral and posterior direction and at an angle greater than $70^{\circ}$ relative to the occlusal plane (Soto, 2012). The direct complications of this technique described in the literature include the appearance of epistaxis, diplopia and impaired accommodation of the lens. There are also complications from incorrect technique performance, in which, instead of accessing the greater palatine canal, the needle passes through the posterior limit of the palatine vault and the anesthetic solution is introduced into the pharynx; in this case, the patient reports the sensation of swallowing a bitter liquid (Malamed, 2006).

\section{CASE REPORT}

The anesthetic technique to block the maxillary nerve through the greater palatine canal was performed on a female patient in the Oral Surgery Clinic at the Faculty of Dentistry, Universidad de los Andes, Chile. The technique involved the application of topical anesthetic in the palatal mucosa (Benzocaine 20\%) followed by disinfection of the area to be injected. The surgeon proceeded to introduce a $42 \mathrm{~mm}$ long needle (Terumo®, Japan) seeking for the greater palatine ca-

\footnotetext{
* Dental Surgeon, Specialist in Oral Surgery. Associate Professor, Morphology Unit, Universidad de los Andes, Facultad de Odontología, Santiago, Chile. ** Associate Proffesor, Department of Oral and Maxillofacial Surgery, Universidad de los Andes, Facultad de Odontología, Santiago, Chile.

*** Dental Surgeon, Specialist in Oral Implantology. Professor, Morphology Unit, Universidad de los Andes, Facultad de Odontología, Santiago, Chile.

***** Dental Surgeon, Specialist in Oral and Maxillofacial Surgery and Periodontics. Professor, Department of Oral and Maxillofacial Surgery, Universidad de los Andes, Facultad de Odontología, Santiago, Chile.
} 
nal, leaving $5 \mathrm{~mm}$ of this needle outside. After aspirating to assess whether or not the needle was inside a blood vessel, the surgeon proceeded to introduce $1 \mathrm{ml}$ of anesthetic (Mepivacaine 3\%, without vasoconstrictor). Immediately following this procedure, the patient reported feeling pain in her left ear and a sensation of fluid in it. After the induction time of this technique passed (5 minutes), there was no evidence of anesthesia in the expected area. Within minutes, the patient began to feel dizzy, and the faculty member in charge of the case proceeded to place the patient in a supine position with her feet raised. The diagnostic hypothesis up until that moment corresponded to a lipothymy. The patient's blood pressure, taken in the dental chair, was $110 / 70 \mathrm{mmHg}$. After having her blood pressure taken, the patient got up from the chair and began jumping to eliminate the feeling of fluid in her ear. She then laid down again on the dental chair, ingested some food, which she vomited soon after. After 90 minutes, despite being normotensive, the discomfort persisted, and the decision was made to take the patient to the emergency room of the Hospital Parroquial de San Bernardo. Again, it was noted that the patient was normotensive with an oxygen saturation of $100 \%$. The patient was hydrated with 1 liter intravenous saline and was discharged by the attending physician on duty one hour later. Patient discomfort persisted at home, so she went to the emergency room of a private clinic, where she was hospitalized. An otolaryngologist evaluated her and a computerized axial tomography (CT Scan) of her head was taken; nothing abnormal was found. Finally, the patient was discharged the next day, with few symptoms and without an accurate diagnosis.

\section{DISCUSSION}

There are no case reports in the literature regarding the development of vertiginous syndrome from incorrect technique for the anesthesia of the maxillary nerve. Vertigo is defined as an illusion of movement, which is usually rotational, experienced by the individual (subjective) or the world around him (objective) (Goic, 1999). Vertigo, in turn, may have a peripheral or central origin depending on the location of the affected anatomical structures. Signs and symptoms of vertiginous syndrome experienced by a patient are loss of balance, nausea, vomiting, nystagmus, and these are often accompanied by alterations in the middle and inner ear such as loss of hearing, feeling of fullness in the ear and tinnitus (Chawla \& Olshaker, 2006).

Both the vestibular (utricle, saccule and semicircular canals) and cochlear systems are innervated by the vestibulocochlear nerve, the eighth cranial nerve. The signs and symptoms experienced by the patient, associated with a complication of the anesthetic technique, are consistent with alterations in balance sensory function (vestibular apparatus) located in the inner ear (Snell, 2001). While the patient was discharged without an accurate diagnosis, she presented signs and symptoms consistent with some degree of alteration of the vestibular system, including the presence of objective vertigo, vomiting and the sensation of fluid in the middle ear on the anesthetized side. It was not possible to confirm or discard the presence of signs such as nystagmus or loss of hearing.

The patient did not have any concomitant disease, the head CT scan obtained did not reflect any alterations and the electrocardiogram was within normal parameters. In addition, examination by both emergency physicians and the otolaryngologist did not yield an accurate diagnosis. After analyzing the data related to this case, we hypothesize that the anesthetic technique used may have triggered this series of events. In support of this hypothesis, we observe that the patient experienced no anesthesia of any of the areas innervated by the maxillary nerve, reported the presence of ear pain during the administration of anesthetic and a sensation of fluid. This led us to suspect that the anesthetic was somehow introduced in the middle and inner ear. The most probably route for access was via the auditory tube. For this reason, we decided to test this hypothesis using anatomical preparations.

Anatomic correlation in cadavers. Measurements were taken from the back edge of the palatal vault to the pharyngeal opening of the auditory tube using eight preserved adult human midheads from the Morphology Unit of Universidad de los Andes. These measurements were made by inserting a $42 \mathrm{~mm}$ long needle (Terumo®) $1 \mathrm{~cm}$ medial to the alveolar process, front to back, until the posterior limit of the horizontal lamina of the palatine bone was reached. The needle was then inserted further at the angulation required to access midpoint of the pharyngeal opening of auditory tube (from the anteroposterior view, see Figure 1. The midheads were photographed using a Cybershot DSC-S75 camera and a tripod. A millimeter ruler was placed at the edge of the image to allow for measurement of the length of the needle from the puncture site to the lower half of the pharyngeal opening of auditory tube. Using the Photoshop ${ }^{\circledR}$ CS5 Extended program, we were able to measure distance in pixels and then convert them to millimeters based on the reference of the millimeter ruler. This allowed us to measure the length in millimeters from the palatal mucosa to the tube and the angle that the needle must have to gain access to the tube in the sagittal plane respect to a horizontal plane (plane from anterior to posterior nasal spine). The results of the measurements taken in the eight midheads are shown in Table I. This table shows that the average angle to access the auditory tube is $39.7^{\circ}$ relative to the horizontal (max: 45.6 / min: 30.9) with a mean length of $21.1 \mathrm{~mm}$ from the palatal mucosa to pharyngeal opening of the auditory tube. 


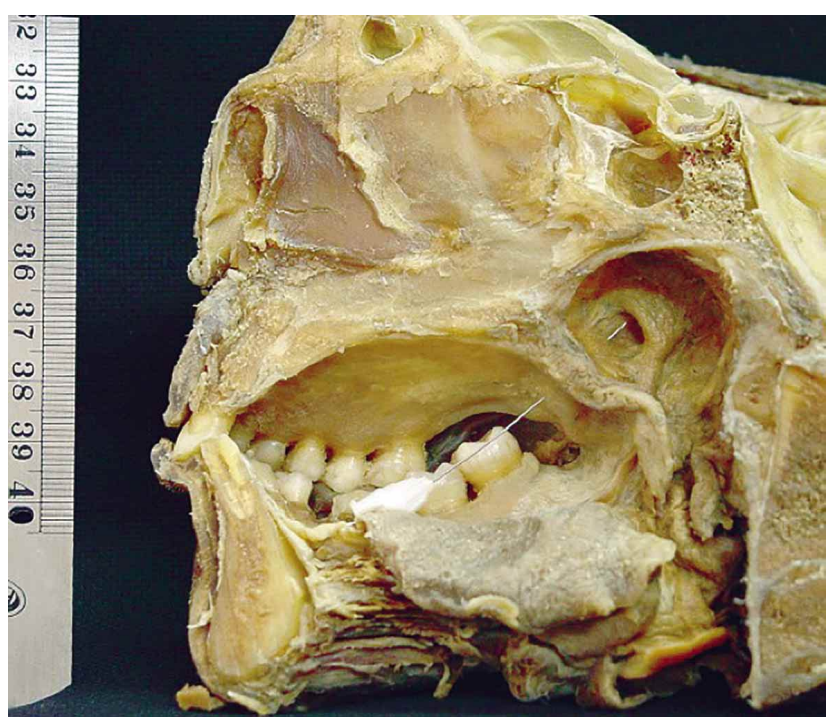

Fig. 1. Injection to the posterior limit of the horizontal lamina of palatine bone with a $42 \mathrm{~mm}$ needle (Terumo® $27 \mathrm{G}$ ).

It is possible that the patient in this case suffered from a vertiginous syndrome caused by the diffusion of the anesthetic solution from the auditory tube into the middle ear through the communication with the anterior wall of the tympanic cavity. Once located in this area, the anesthetic could spread through the vestibular window towards the membranous vestibular system, which houses the utricle and saccule. Finally, the anesthesia may have blocked the vestibular nerve endings located in this area. A hyperextended head position is necessary for the application of the anesthetic technique via the greater palatine canal, combined with reduced angulation of the needle, and a posterior puncture in the palate can result in access to the auditory tube and may have facilitated the entry of the anesthetic into the ear.

Table I. Angle and length of the trajectory of the needle.

\begin{tabular}{ccc}
\hline Midface & Angle & $\begin{array}{c}\text { Length of the } \\
\text { needle trajectory }\end{array}$ \\
\hline $\mathbf{1}$ & 35.6 & 22.64 \\
$\mathbf{2}$ & 46 & 18.99 \\
$\mathbf{3}$ & 43.5 & 21.7 \\
$\mathbf{4}$ & 45.6 & 20.12 \\
$\mathbf{5}$ & 30.9 & 19.43 \\
$\mathbf{6}$ & 32 & 20.36 \\
$\mathbf{7}$ & 43.9 & 22.8 \\
$\mathbf{8}$ & 40.1 & 22.8 \\
Mean & 39.7 & 21.105 \\
\hline
\end{tabular}

Angle from the horizontal plane and the length of the trajectory of the needle from the palate to the pharyngeal opening of the auditory tube in the eight midfaces studied.
SOTO, R.; CÁCERES, F. \& LANKIN, J. Síndrome vertiginoso asociado a técnica anestésica incorrecta para bloquear el nervio maxilar vía canal palatino mayor: Reporte de caso y correlación anatómica en piezas cadavéricas. Int. J. Morphol., 32(3):786-788, 2014.

RESUMEN: La técnica anestésica vía canal palatino mayor tiene como objetivo abordar al nervio maxilar en la fosa pterigopalatina, anestesiando un gran territorio, incluyendo la pulpa y periodonto de la hemiarcada correspondiente. Después de haber aplicado esta técnica en una paciente y no obteniendo el resultado esperado, esta comenzó a experimentar vértigo, náuseas, sensación de líquido en el oído y vómitos. Fue evaluada en el servicio de urgencias del Hospital Parroquial de San Bernardo y en una Clínica Privada, sin lograr un diagnóstico preciso y realizando solo un tratamiento sintomático. Al día siguiente fue dada de alta con baja sintomatología, la cual desapareció totalmente durante el día. Se propone la hipótesis de una difusión del anestésico hacia el oído medio e interno mediante el tubo auditivo. Esto explicaría por un lado la sintomatología vestibular y por otro la ausencia de anestesia en los dientes y territorios esperados. Además se realizó una correlación anatómica en cadáveres, utilizando 8 hemicabezas conservadas y siguiendo el posible trayecto de la aguja desde la mucosa palatina hasta el orificio faríngeo de la tuba auditiva. Se concluyó que el síndrome vertiginoso experimentado por la paciente se pudo deber a una técnica fallida al nervio maxilar vía canal palatino mayor con ingreso de la aguja al tubo auditivo, difundiendo el anestésico hacia el oído medio.

PALABRAS CLAVE: Vértigo; Anestesia Dental; Tubo Auditivo; Nervio Maxilar.

\section{REFERENCES}

Chawla, N. \& Olshaker, J. S. Diagnosis and management of dizziness and vertigo. Med. Clin. North Am., 90(2):291-304, 2006.

Goic, A. Mareos y vértigo. In: Goic, A.; Chamorro, G. \& Reyes, H. (Eds.). Semiología Médica. 2nd ed. Santiago de Chile, Técnicas Mediterraneo, 1999. pp.63-5.

Malamed, S. F. Técnicas de anestesia maxilar. In: Malamed S. F. (Ed.). Manual de anestesia local. $5^{\text {th }}$ ed. Madrid, Elsevier, 2006. pp.189225.

Snell, R. S. Núcleos de los nervios craneanos y sus conexiones centrales $y$ distribución. In: Snell, R. S. (Ed.). Neuroanatomía Clínica. $5^{\text {th }}$ ed. Buenos Aires, Editorial Médica Panamericana, 2001. pp.329-69.

Soto, R. Técnicas anestésicas tronculares maxilares. In: Sole Besoaín, F. \& Muñoz, F. (Eds). Cirugía Bucal, para el pregrado y odontólogo general. Bases de la cirugía bucal. Santiago de Chile, AMOLCA, 2012. pp.190-202.

Correspondence to:

Dr. Reinaldo Soto Norambuena

Unidad de Morfología, Facultad de Odontología

Universidad de los Andes

Monseñor Álvaro del Portillo 12455

Las Condes, Santiago - CHILE

Email: rsoto@miuandes.cl

Received: 22-07-2013

Accepted: 22-05-2014 